\title{
Implementation Processes of Social Protection Policy in Indonesia: Study of Prakerja Card Program
}

\author{
Fitri Kurnianingsih ${ }^{1}$, Mahadiansar ${ }^{2}$, Ramadhani Setiawan ${ }^{3}$ \\ 1,3Department of Public Administration, Faculty of Social and Political Sciences, Raja Ali Haji Maritime University, \\ Jl. Raya Dompak Tanjungpinang, Riau Islands 29111, Indonesia. \\ 2Public Administration Post Graduate Study Program, Faculty of Administration Science. Brawijaya University, \\ J. MT Haryono No 169 Malang City, East Java 65141, Indonesia.
} Corresponding Author: mahadiansar@student.ub.ac.id

\section{Article Info}

Keywords:

Implementation;

Social Policy;

Pra KerjaCard.

Kata Kunci:

Implementasi;

Kebijakan Sosial;

Kartu Prakerja.

\begin{abstract}
In recent decades, in Indonesia, there have been many social protection policies as social and political agendas that are not public knowledge in the form of "Kartu Sakti". One of the magic cards that are very popular during the COVID19 pandemic is the Prakerja card. The purpose of this paper is to analyze the process of implementing the Grindle theory (2017) involving interest actors. The research method was carried out qualitatively by using secondary data which was analyzed in depth. The results show that the grindle theory includes Content of Policy and Content of Implementation in the social protection policy implementation process of the Prakerja card program, there are problems and are difficult to implement properly by the implementers, this causes the real purpose of social protection policies has not shown the impact on community welfare during the COVID -19 pandemic compared to other social protection policy programs on target. also, the actors of the Prakerja card program have different interests and goals from both the implementor and the recipient side. The Indonesian government is obliged to evaluate and take strategic and regulatory action in the form of pra Kerja program innovation as a long-term priority scale to avoid any gap in the process of implementing social protection policies that adversely affect the welfare of the Indonesian community.
\end{abstract}

Abstrak: Dalam beberapa dekade ini, Di indonesia banyak sekali kebijakan perlindungan sosial sebagai agenda sosial dan politik yang tidak menjadi rahasia umum dalam bentuk "kartu sakti". Salah satu kartu sakti yang sangat populer dalam masa pendemi COVID-19 yaitu kartu prakerja. Tujuan tulisan untuk menganalisis proses implementasi teori grindle (2017) yang melibatkan aktor kepentingan. Metode penelitian dilakukan secara kualitatif dengan mengunakan data sekunder yang di analisis secara mendalam. Hasil menunjukan teori grindle meliputi Content of Policy dan Content of Implementation pada proses implementasi kebijakan perlindungan sosial program kartu prakerja terdapat permasalahan dan sulit di implementasi dengan baik oleh para implementornya, hal ini menyebabkan tujuan sesungguhnya kebijakan perlindungan sosial belum memperlihatkan dampak kesejahteraan masyarakat pada masa pandemi COVID-19 dibandingkan program kebijakan perlindungan sosial lainnya tepat sasaran. Selain itu aktoraktor program kartu prakerja memiliki kepentingan serta tujuan yang berbedabeda baik dari sisi implementor dan sisi penerima. Pemerintah indonesia wajib melakukan dievaluasi serta mengambil tindakan secara strategi pada teknis dan regulasi berupa inovasi program kartu Prakerja sebagai skala prioritas jangka panjang agar tidak terjadinya kesenjangan proses implementasi kebijakan perlindungan sosial yang berdampak buruk kesejahteraan masyarakat indonesia.

Article History: Received: 2019-11-04, Revised: 2020-06-13, Accepted: 2020-09-12 


\section{INTRODUCTION}

In developing countries, there are many roles of government in implementing policies that lead to a long-term distribution of social protection programs (Lithur, 2015; Ouma, 2019; Shaban, 2011; Warfa, 2019). Social protection policies are intended for developing countries facing the global crisis in economic emergencies. Social protection programs have a very broad perspective both in accordance with the needs and disadvantages of the community (Xenia, 2014). However, in Indonesia, there are currently many innovations in social protection policies in various forms that greatly influence the dynamics of democratization and politics, both at the national and regional levels (Sumarto, 2018). Social protection in Indonesia as a solution to poverty reduction in sustainable economic development, social protection strategies are aimed at the poor and provide opportunities to contribute to economic development (Supriyanto et al., 2014).

Policies on social protection programs are still being developed for good implementation. Then there are many social protection programs such as the equal distribution of education (Nurmalasyiah \& Sumburwati, 2017; Rohaeni \& Saryono, 2018; Sulhan \& Sasongko, 2017), direct cash assistance (BLT) to the less fortunate (Suharto, 2015), The Family of Hope Program (PKH) as an effort to reduce poverty (Bakhtiar \& Qodir, 2015) as well as other social assistance that has an impact on COVID-19 (Iping, 2020; Vaziralli, 2020). With the existence of various forms of social protection programs, the role of the government in poverty alleviation will be appreciated by the community with the right target. to accelerate economic recovery in Indonesia, social protection policies take various forms, including through the family hope program (PKH), basic food cards, Pra Kerja cards, and cash social assistance (bansos).

One of the popular social protection policies during President Joko Widodo's administration is the Prakerja card program. Together with this program, there are several other government policies in the field of education such as strengthening vocational programs, strengthening PAUD administration, and increasing the effectiveness of educational aid distribution (BOS, PIP, and LPDP) with the aim of supporting gradual reform of the social protection system. (Alika, 2020) in her writing explains that the government previously budgeted IDR 20 trillion for the Pra Kerja card program. This program is aimed at 5.6 million cardholders in 2020. Thus, each Pra Kerja card participant will get a benefit of IDR 3.55 million per person.

According to Consuello (2020:94) social protection policies on Prakerja cards as a form of an effort to develop basic competencies in improving quality in finding and opening job opportunities as needed during the COVID-19 pandemic. In the presidential regulation number 36 of 2020 concerning Work Competency Development through the Prakerja Card Program, the regulations governing its implementation refer to the Regulation of the Minister of Finance (PMK) Number 25 / PMK.05 / 2020 concerning Procedures for Allocation, Budgeting, Disbursement, and Accountability of Funds Prakerja Card. This means that social protection program policies are very focused on strategic efforts in economic recovery during the COVID-19 pandemic and innovation in economic development (Setiawan \& Mahadiansar, 2020:416). The Prakerja Card Program is a program with the mission of developing entrepreneurial competencies and competencies to create jobs for those who need work in increasing the capacity of individual capabilities for business actors. In line with the social protection policy process being implemented, the facts that occur are based on data from the Directorate General of Treasury, Ministry of Finance as of 12 September 2020, the realization of the Prakerja Card program has been realized amounting to IDR 2.41 trillion or equivalent to 12.05 percent of the total budget of IDR 20. trillion. This Prakerja card has also been distributed by 4.68 million participants

Besides, there are many gaps in the process of implementing the Prakerja Card social protection program. Ramadhan (2020) in his writing (Kompas.com) states that many of the findings of the Corruption Eradication Commission (KPK) on technical implementation are not right on target and lack efficiency that has the potential to harm state finances and have the potential for conflicts of interest Furthermore, in the Prakerja Card program, many training provider platforms have difficulty purchasing training due to changes in the system of governance changes as stated in Permenko No.11 of 2020. The purpose of this research is to see the administrative and political processes in implementing social protection policies in the Prakerja card program using the theory of Grindle (2017) which focuses on solving problems, policies that 
have been made, and the potential for political currents to have an impact on implementation. Then the political context on the potential social protection policies from policy implementation also provides the strategies needed to create conditions for more effective policy implementation.

The implementation of a public policy has two choices of steps, the first is directly implementing it in the form of a program or through the formulation of a derivate policy or derivatives of the public policy (Yudiatmaja, 2016). The sequence in policy implementation can be observed from the program to the project and the activity. A policy is derived in the form of programs which are later reduced to projects, and finally in the form of activities, whether carried out directly by the government, the community, or the government-community cooperation. Grindle (2017) in its latest edition of the book introduces the implementation model as a political and administrative process. The model describes the decision-making process carried out by various actors, where the final output is determined by both the program material that has been achieved and through the interaction of decision-makers in the context of administrative politics.

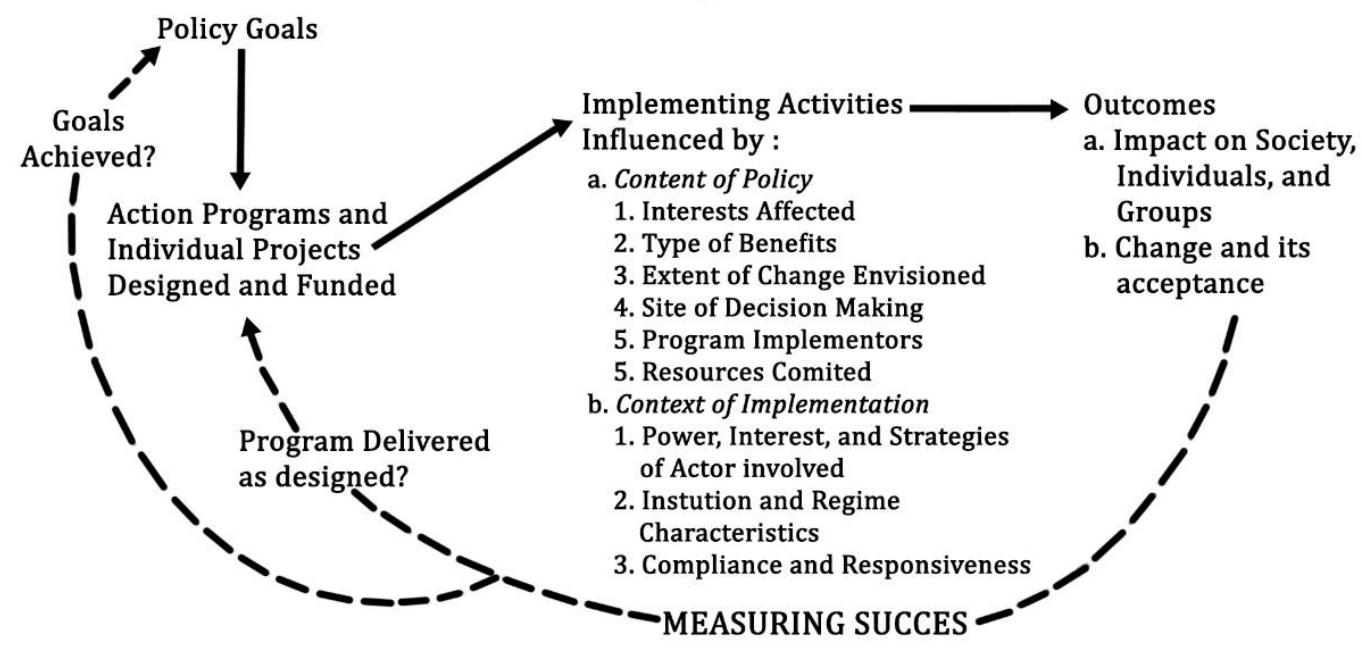

Figure.1 Implementation as a political and administrative process Source: Grindle (2017)

According to Grindle, the success of public policy implementation is determined by the level of policy implementation, which consists of the content of the policy and the context of implementation. From these two aspects, after implementation will know the outcomes (final results) so based on the picture above, this study takes the theory of Grindle which states that the success of policy implementation can be influenced by the two variables above. The content of policy includes the extent to which the interests of the target group or target groups are contained in the content of the public policy, then there are types of benefits received by the target group, the changes desired by the policy.

Then, whether the location of a program is correct and a policy has mentioned its implementers in detail. There are also resources that in program implementation are supported by adequate resources. Then the context of implementation variable includes several criteria including how much power, interests, and strategies are owned by the actors involved in policy implementation, then the characteristics of the institutions and regimes in power and the level of compliance and responsiveness of individuals and target groups in the policy implementation process.

\section{RESEARCH METHOD}

Moleong (2012) defines Qualitative methods as research procedures that produce descriptive data in the form of written and spoken words from the community and observable behavior. In line with this definition, Kirk \& Miller (1986) Qualitative research is a particular tradition in social science that fundamentally depends on observations of humans, both in its area 
and in terms. According to (Taylor et al., 2015) A case study is a detailed examination of a background or a subject or a document storage area, or a particular event. Surakhmad (1980) limiting the case study approach as an approach by focusing on a case intensively and in detail.

While Yin (2018) provides a more technical definition with an emphasis on characteristics. Ary et al., (1985) explaining the case study the researcher should try to test units or individuals in depth. The type of data used in this research, namely secondary data is the support obtained from relevant sources, usually in the form of taking documents, reports, or data, as well as other supporting material and information in the research (Zed, 2014). Then an in-depth analysis is carried out based on the grindle theory in seeing the implementation process of the social protection policy in the Prakerja card program in Indonesia.

\section{RESULT AND DICUSSION \\ Content of Social of the Pra Kerja Card Program Social Protection Policy Interest Affected}

Quoting from Pressman \& Wildavsky (1973) a policy related to cause and effect depends on a long chain, so it will easily experience cracks, as the longer the chain of causality, the greater the interrelationship between the linkages and the more complex its implementation. It could also mean that the more links there are in the chain, the greater the risk that some of them will prove weak or cannot be implemented properly. Based on this explanation, it can be concluded that the Prakerja card program policies that affect many interests are:

1) The Prakerja card program is the responsibility of the coordinating ministry for the economy of the Republic of Indonesia as the head of the work creation committee and then forms the executive management of the Prakerja card program, so the interests of the coordinating Ministry for the economy of the Republic of Indonesia do not apply because it has given authority in technical implementation in managing the Prakerja card program. This causes problems related to social protection policies in the implementation of the Prakerja card program because the granting of authority is fully on the management of the card program executor.

2) The management of implementing the Prakerja card program, its importance is to prepare and implement regulations for various online training as well as to select digital platform partners and training incentive payment partners for training following existing rules and regulations. The main digital platforms involved at this time include the Ministry of Manpower (Kemenaker), Tokopedia, Pijarmahir, Bukalapak, Maubelajarapa, Pintaria, and Sekolahmu and the incentive payment partner platform including Bank Negara Indonesia (BNI), OVO, GoPay, and Linkaja.

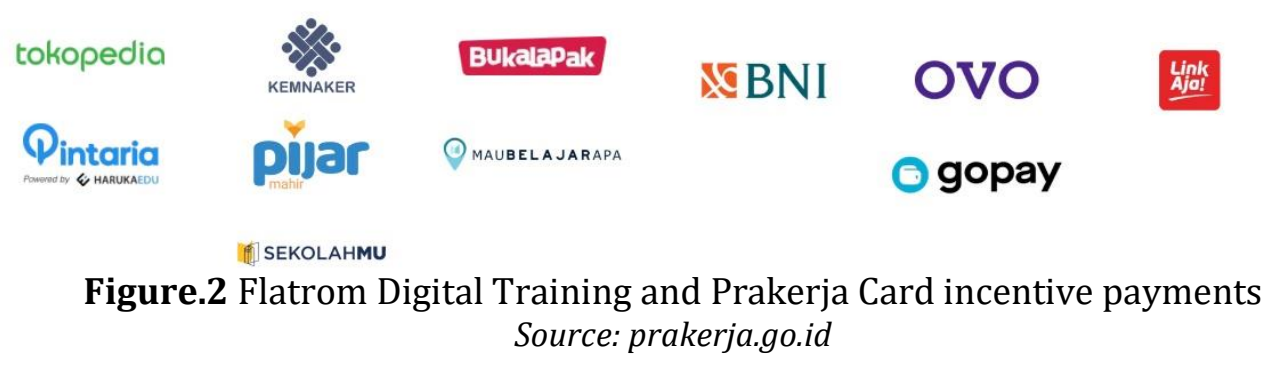

3) Flatform Digital Training has an interest in providing various forms of training according to the needs of training participants who are declared entitled to have Prakerja cards, with the interest of digital platform companies to increase the industrial revolution and increase the capacity for digitalization in Indonesia during the COVID-19 pandemic.

4) Flatform Incentive payment, has the interest to distribute training incentives for 4 months with an incentive amount of IDR 600,000, - per month and a survey incentive of IDR 50,000 for three surveys for each Prakerja participant.

5) Community affected by the COVID-19 pandemic have an interest in participating in the pra Kerja card program as recipients of social protection assistance. A Community who 
are entitled to the pra Kerja card program have the responsibility to complete the training as a process of increasing individual competence by creating jobs, especially those affected by layoffs, then after completing the training they get incentives that are intended for the survival of pra Kerja program participants while still being able to carry out activities and be active in during the COVID-19 pandemic. All Indonesian citizens aged 18 years and over and not currently attending formal education may register. To respond to the impact of the COVID-19 pandemic,

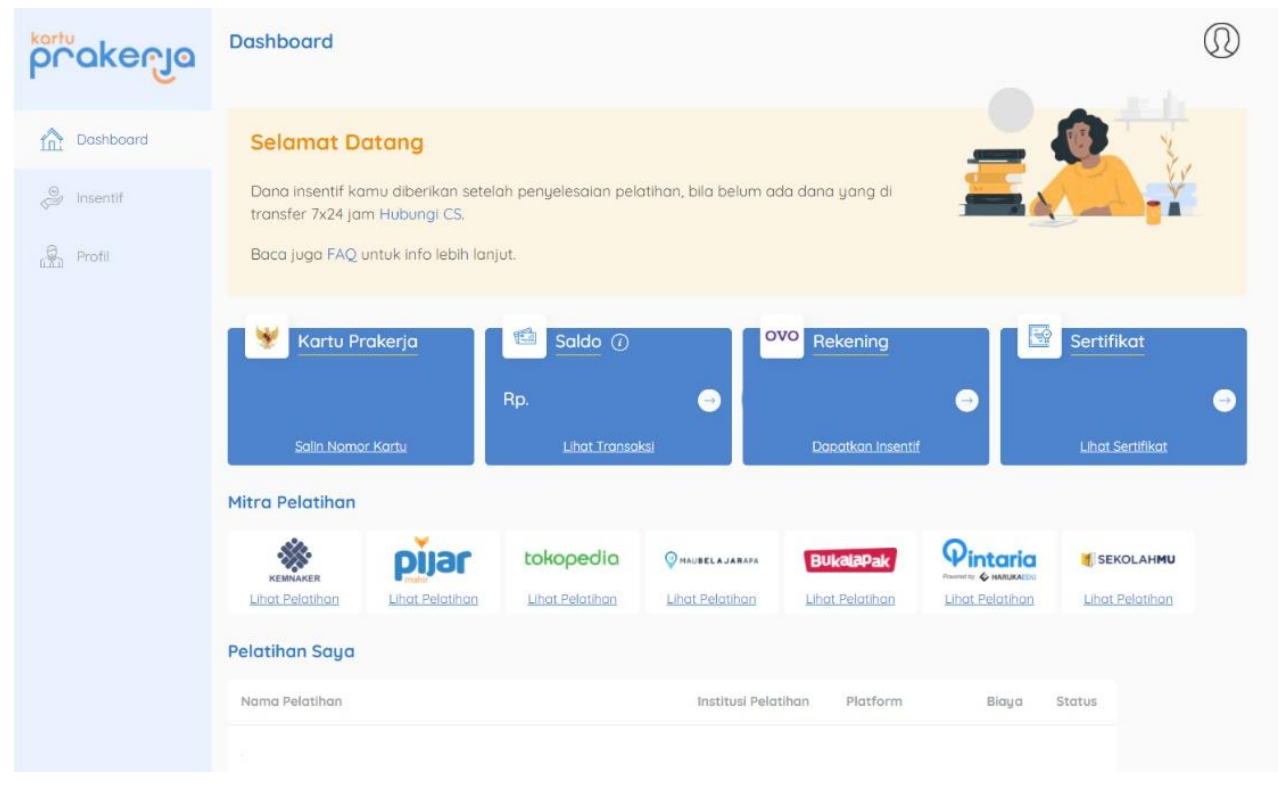

Figure.3 Display of the Prakerja program that is accessed by the Indonesian community if graduated to become Prakerja participant. Source: pra Kerja.go.id

The Prakerja Card Program will temporarily prioritize workers/laborers who are sent home as well as micro and small business actors who are affected by their livelihoods. The social protection policy process for the Prakerja card program involves many interests and each of them has differences both technically and in terms of regulations, therefore the implementation process for the Prakerja card program is difficult to implement properly, because there are many interests that do not have a sustainable interest relationship, meaning that in such interest will a have constraint in the technical of Prakerja card program. The number of government agencies or corporate platforms in the implementation process is ineffective and inefficient when communities need social protection programs during the COVID-19 pandemic throughout Indonesia.

\section{Type of Benefit}

The Research result of Samnuzulsari \& Yudiatmaja (2018) social protection policies as a form of political strategy in realizing campaign promises on the "Sakti" or "Magic" card by the elected leaders. As in the Indonesian presidential election in 2019, it is known that the Prakerja Card program is a realization of the political promises of the Indonesian president and the currently elected Vice President of the Republic of Indonesia, Joko Widodo and Ma'aruf Amin. The current campaign promise is felt by the beneficiaries of as many as 3 magic cards, namely the Cheap Groceries Card, the Indonesia Smart-College Card (KIP College), and the Prakerja Card which is currently very popular. 


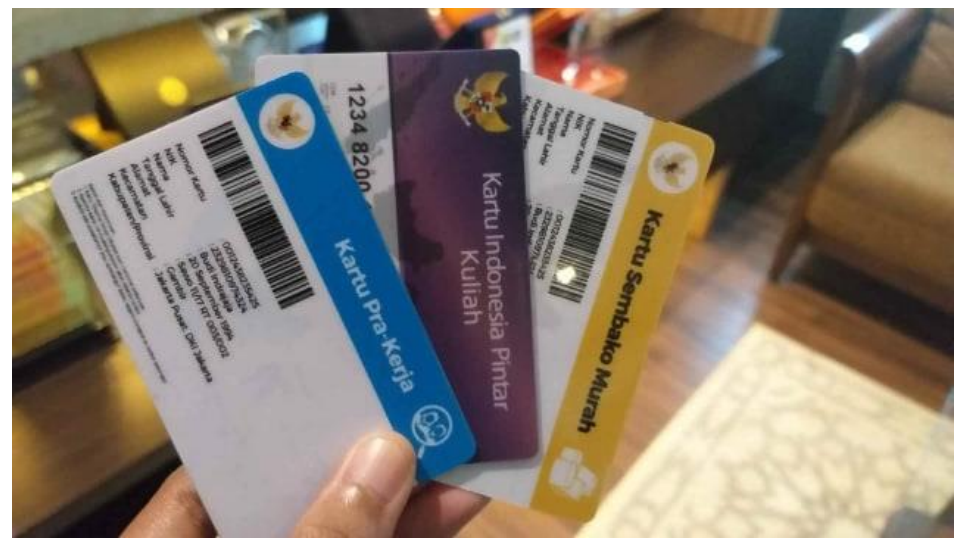

Figure.4 "Sakti" cards for the Social Protection Policy Program during the Joko WidodoMa'ruf Amin campaign in the 2019 presidential election Source: Kumparan.com

The social protection policy in the Prakerja card program brings the greatest and most fundamental benefits the Indonesian community who are affected by layoffs and the increasing difficulty of finding work during the COVID-19 pandemic to survive after receiving incentives from the Prakerja card program. On the other hand, the benefits received by participants of the pra Kerjacard program even though they already have the competence according to the wishes of the Prakerja participants, the benefits in realizing are very small, because participants who receive these benefits are only felt by those who have the technology to access the training platform, then the implementation of the social protection policy difficult to hit the target for the recipient.

Based on the explanation of the analysis, it can be concluded that the benefits received by the implementation of social protection policies in the Prakerja card program have not reached all of the targets precisely, only those who have access to technology because not all Indonesians can access the digitalization technology, it looks like a local community. borders in the 3T area (left behind, frontier, outermost), so this causes the target is not right so that only the community have some interest in the pra Kerjacard program. Referring to Presidential Decree No. 131 No. 2015 , there are 122 districts in the 3T area based on the criteria of the community's economy, human resources, facilities and infrastructure, regional financial capacity, accessibility, and regional characteristics.

\section{Extend of Change Envisioned}

A social protection policy must have an impact on changes, especially for the poor during the COVID-19 pandemic. Recent research results fromKurniawansyah et al (2020:130)the need for strategic policies that provide changes in economic externalities in Indonesia. The Prakerja program, which was not previously intended for the COVID-19 pandemic, changes in regulations and rules regarding the implementation of the Prakerja card program, causing conflicts between the executive (government) and the legislative (DPR). This is because the digital platform for providing training does not overtake the legislature, so it is necessary to change regulations that make it easier to realize the Prakerja card program.

The social protection policy in the Prakerja card program has an educational impact on digitalization on the development of job competence and entrepreneurship aimed at job seekers, workers / laborers who have been terminated, and/or workers/laborers who need increased competence, including micro and small business actors. Then The degree of change desired by the management implementing the pra Kerjacard program in social protection policies will lead to the development of individual competencies in order to create jobs for the community affected by the COVID-19 pandemic.

This can be seen from the budgeting from wave 1 to wave 10 amounting to 20 trillion and the program will continue to be budgeted for the 2021 State Budget based on data from the 
Coordinating Ministry for the Economy. The flagship program during the COVID-19 pandemic under the leadership of the President of the Republic of Indonesia, Joko Widodo-Ma'aruf Amin under the auspices of the Coordinating Ministry for the Economy, so it is certain that the concept of social protection policies in the Prakerja card program will have an impact on fundamental improvements/changes in the management of the Prakerja card program. by 2021. These changes include evaluating changes or regulations for training provider partners and incentive payment partners to make them more effective.

\section{Site of Decision Making}

The decision making is entirely in the rules and regulations of the Job Developer Committee established through Presidential Regulation Number 36 of 2020 concerning Work Competency Development through the Prakerja Card Program as amended by Presidential Regulation Number 76 of 2020. However, this program is the result of a collaboration between the government and private sector platform provider. However, in fact, the decision making did not involve the legislative (DPR). Many of the legislatures are suggesting stopping the Prakerja Card program. One of them is the statement made by the member of Commission II of the Indonesian Parliament Guspardi Gaus.

"The government must hear input from many parties stating that the Pra Kerja Card program is problematic from the start to the implementation stage. Moreover, in the current situation, the government is focusing on preventing the spread of Covid-19 which has an impact on the sluggishness of the national economy. the community in accessing their food needs. This online training activity has the momentum to be inappropriate to do in the midst of the threat of the Covid -19 outbreak. It is better if you just cancel the pra Kerjacard program and divert the budget into direct cash assistance (BLT). right to be given to the poor community, considering that much lower class community are threatened with losing their purchasing power due to loss of jobs and income "(dpr.go.id, Sunday,3 May 2020).

However, in reality, the government took the decided to continue the Prakerja card program until 2021. There is a positive position in central government decision making, namely making it easier to coordinate or directing both the rules and regulations as well as the technical implementation of the social protection policy in the Prakerja card program. . However, the problem is that the local government does not involve the local government so that the participation of the local government will affect the recipients of Prakerja assistance through the dualism of supervision so that many perspectives of the community who are not involved in decision making in determining the recipients of the Pra Kerja card program are deemed inappropriate in the conditions of the COVID-19 pandemic.

\section{Implementors Program}

The implementation failure of social protection policies is in determining targets to be achieved and the government's role in the synergy of an integrated database between the central and regional governments and the private sector in implementing social protection policies (Habib \& Laksono, 2019:135). The implementation of the Prakerja card program must strengthen the supervisory function so that in its implementation, the implementer must first understand the possibilities that may occur in the implementation of the pra Kerjacard program. Implementation will not run well if there is no implementer.

The implementer of the Prakerja program policy is the Coordinating Minister for the Economy as the Chair of the Job Creation Committee is the person in charge of the Prakerja Card program and the Executive Management is the program, operational operator. The person in charge of technical implementation is lead by the Executive Director and his staff, namely the director of operations, director of technology, director of communication, and development partnerships. The implementation of the Ministry of Economic Affairs emphasizes the implementation and adjustment of the focus of the Prakerja Card Program be accelerated as one of the steps for implementing Presidential Instruction (Inpres) No. 4 of 2020 concerning Activity 
Re-focusing, Budget Reallocation, and Procurement of Goods and Services for the Acceleration of Handling COVID-19.

However, the different technical implementation of the pra Kerjacard program has caused problems, including a number of Pra Kerja card recipients who still have difficulty purchasing training, the duration is too long to get a training certificate as a condition of receiving training incentives and failure to receive pra Kerjaincentives is transferred by Prakerja payment partners (Account \& E-Wallet). This shows that there is a lack of a performance component in overcoming technical problems in the Pra Kerja card program for Prakerja program participants that still have technical errors and constraints, even there will still be problems arising in the implementation of social protection policies so that many perceptions of the public judge the lack of professionalism of the administrators in the Pra KerjaCard program.

\section{Resource Commited}

Quoting Edward (1980) Policy implementation must be supported by resources, both human, material, and methodical resources. Even though the goals, objectives, and content of the policy have been clearly and consistently communicated, if the implementor lacks the resources to implement it, the policy implementation will not go well (Purwitasari, 2012). It is clear that policy implementation will not work if there are no resources. Resources here are meant about financing. The financing for each pra Kerjacard user will receive financing for training in skilling (ability), upskilling (capacity building), and re-skilling (ability replacement). Training funding assistance of up to IDR 1 million per person will be paid directly to training institutions.

Then, Prakerja card users will get a direct incentive of IDR 600 thousand per month which lasts for four months. The incentive is intended as pocket money for the participants. In addition, Prakerja card users will get a job survey facility worth IDR 150 thousand, which is paid to training institutions. Based on these data, there are incentives adjustments or other social assistance in other social protection policy programs, one of which is direct cash assistance from the Ministry of Social Affairs. So regarding the existing resources in implementing policies in a transparent and open manner regarding incentive recipients for social protection policies in the Prakerja Card program so that it tends to experience a sustainable program in accordance with what has been planned and implemented properly.

\section{Content of Implementation of the Pra KerjaCard Program Social Protection Policy Power, Interest, And Strategies of Involve Actors}

Satibi \& Sudrajat (2019) The results of his research emphasize that decision making is a systematic approach to alternatives that are realized and take action that takes into account the most appropriate action, even decision making is often argued as determining conclusions on a case to be implemented. The social protection policies in the Prakerja Card program are consistent with a focus on developing individual competencies. The implementation of the Prakerja card program policy is still low on the achievement of reducing the number of unemployed, this is the high number of the spread of the COVID-19 pandemic in Indonesia despite implementing social distancing, large-scale social restrictions, or regional quarantine.

So that the participants of the Prakerja card program only saved economic conditions during the 4 months the incentives were given. So that community tends to secure their respective interests, such as their goal to stay alive with the incentives needed by the participants by neglecting the government's original goal of creating jobs. The powers, interests, and strategies of stakeholders involved in social protection policies are not much different from other programs. Grindle (2017) stated that "frequently, the goals of the actors will be in direct conflict with each other and the outcome of this conflict and consequently of who gets what, will be determined by the strategies, resources, and power positions of each of the actors involve Prakerja card programs and communities that participate as participants who are directly involved in the technical process from registration to receiving training incentives.

The capacity of the Prakerja Card program participants has the power to receive rights and obligations in participation in order to make a living for their daily needs, while the government's interest is to reduce unemployment. It can be seen that power and interests have different 
strategies in achieving goals. Due to the different powers, interests and strategies of the actors, it is difficult for this policy to be improved both technically and in outcomings.

\section{Institution and Regime Characteristic}

The environment of an implemented policy will affect the success or failure of the policy, so in this section, we want to explain the characteristics of an institution that will influence a policy. The implementation of policies can lead to conflicts among groups whose interests are influenced. Ultimately conflict resolution will determine who gets what. Quoting Edward (1980) The ideology of implementing the policies is called a disposition. So it's clear that "if implementers are well exposed toward a particular policy, they are more likely to carry it out as the original dicision-makers intended. But when implementors' attitudes or perspectives differ from the dicision-makes, the process of implementing a policy becomes infinitely more complicated.

This statement states that the typical personality or view that is relatively the same between policymakers and policy implementers has a positive correlation with the success of policy implementation. Due to the conformity of views regarding the policies to be implemented, the implementers of the policies carry out these policies seriously and fully, as if they themselves own the policies. Grindle, (2017:70) said that "the extent to which political regimes and administrative organizations have the power to implement the policies they are committed to". The extent to which a political regime and administrative organization have the power to implement the policies to which it is committed.

A regime is a series of regulations, both formal and informal, that govern the implementation of a government and its interactions with the community economy. The regime in power today is a democratic regime. With several laws related to social protection policies that regulate the Development of Work Competence through the Prakerja Card Program, one of which is the management of the Prakerja card program executor not through the decision to auction the procurement of goods and services by the Government Goods / Services Procurement Policy Institute (LKPP). This was stated by the Executive Director of Implementing Management for the Prakerja Card Program, Denni Puspa Purbasari

"LKPP, which we invited since the beginning of the Perpres drafting, said this was not an auction for the procurement of goods and services during pre-employment. Because the money goes to Babun (National General Treasurer) and the money goes directly to the participants, not the ministry/institution. Presidential Decree No. 16 of 2018, The criteria are in Permenkeu and we have posted the information on Instagram pre-employment.go.id. So the community chooses for themselves, it's like a buffet. The government offers this menu, then participants can choose for themselves"

The current government in implementing policies related to social protection policies is a centralistic regime. Where most regional affairs are held by the center. Especially in the use of human resources, including social protection policies. The current regime is considered centralized, namely the implementation of regulations regarding the management of the pra Kerjacard program which makes the central government the dominant actor in managing social protection policies. At the same time, it is like providing an almost complete limit on the authority of the coordinating ministry of the economy as a working copyright committee with the executive management of the Prakerja card program.

\section{Compliance and Responsiveness}

Compliance and Responsiveness describe the extent of compliance and responsiveness of the implementer in responding to a policy. Compliance and responsiveness cover the circle in the implementation environment so that the objectives of the policy/program can be achieved, the implementers or stakeholders involved in it must be responsive to the needs of the target group. This includes responsiveness in resolving conflicts when policy implementation is running. Responsiveness can also be called the level of responsibility of the policy implementer, if the responsibility for implementation is minimal, it will result in implementors losing information to 
evaluate program achievements and will experience a crisis of support which is important for achieving program success. be it support from the target group or from the policy implementers themselves. Quoting Hogwood \& Gunn (1984) those in power can demand and get obedience. The statement explained that there must be a condition of complete submission and no rejection of orders from anyone in the administrative system at all.

If there is a tendency to not comply, then the parties in authority must be able to make policies/regulations that explain that those who have the authority should also have power and be able to guarantee the development of comprehensive obedience to all other parties and their agreement and cooperation very necessary to carry out the program activities that have been determined. Research result Rusyidi et al (2017:140) Concerning the analysis of special purpose social protection policies, concludes that the main problem should be policy development oriented towards prevention, strengthening family capacity and resilience, diversifying funding, and implementing optimal monitoring and evaluation so that it can be implemented for the effectiveness of social protection.

Grindle (2017) said that "in additional, without a considerable amount or responsiveness during implementation, public officials are deprived of information to evaluate the program achievement and of support crucial to its a success". Without a large ladder during policy implementation, public officials may lose information to evaluate program achievements and lose support for their success. Indeed, in policy implementation it should be clear about more detailed rules and can guarantee the growth and development of an obedient attitude by all parties. In implementing social protection policies in this pra Kerjacard program, the tendency to disobey and be irresponsible is not avoided.

The challenge of the government is simply to increase trust in the public so that there is a need for an agreement of trust between the government and its own citizens through mutual agreement (Sentanu, 2015). different from the social protection policy in the Pra Kerja Card program which reduces public trust in the management of Prakerja cards, one of the causes of implementation is not going well. In addition, participants did not obey the rules given by the executive card program management as the owner of the program implementation. The results of Prakerja card program incentive recipients cannot be controlled directly for the beneficiaries.

The management of implementing the Pra Kerja card program has a desire to facilitate the post Prakerja card program training by collaborating on the basic competencies that Prakerja card participants already have, however, the management of implementing the Prakerja card program does have a limited mechanism. There is no operational procedure system specifically to regulate Post-Prakerja so that it looks like the low management responsibility for the pra Kerjacard program implementers. Research result (Ramadani, 2019) explained that by building good communication between the government and community participation, the success of public understanding will be created, this will enable the participatory creation of the Prakerja participants because the surrounding Prakerja Card participants fully understand the existence of social protection policies. Pra Kerja participants really understand the existence and benefits as well as the objectives of the pra Kerjacard program.

Based on the results of the above analysis, it can be concluded that the level of compliance and responsibility for the management of the pra Kerjacard program is still low. The management of the Prakerja card program that only relies on training platforms through the concept of digitizing the online system to achieve implementation goals, does not yet have an operational system for implementing direct training procedures while maintaining health protocols to prevent new clusters from spreading COVID-19. Then the Prakerja card participants with their expertise offer to a community who cannot use technology finally use training services from Prakerja participants to other communities with the capital of Identity Cards (KTP) and Family Card Numbers (KK). In contrast to other social protection policies (BLT, PKH, etc.)

\section{CONCLUSION}

The implementation process of the social protection policy on the Prakerja card program has not shown the impact of improvement and economic or social changes during the COVID-19 pandemic that the community expected. The goal of implementing the social protection policy 
made by the Indonesian government in the Prakerja card program should be able to provide support for the welfare of the community in increasing competence to create new jobs. The failure to achieve the maximum goal is due to the designation of social protection policies that were not used in emergencies. There needs to be a deeper study of the management of the Prakerja card program regarding clear program orientation, program innovation, and program design that should be controlled by the Job Creation committee of the coordinating ministry for the economy of the Republic of Indonesia.

The Indonesian government should carry out a mentoring process by establishing a Supervisory Body for the Job Creation Committee which will pay attention to social protection policies in the Prakerja card program. The establishment of the Supervisory Board of the Job Creation Committee actually has a control function in anticipating and overcoming violations that occur in the social protection policy in the Prakerja card program that will continue in 2021. If it is not supported by the firmness of the implementers and sanctions that refer to legal products, it could be There is a potential for deviation in the actual role of the social protection policy of the Prakerja card program in Indonesia which will certainly have an impact on future social protection policies.

\section{ACKNOWLEDGEMENT}

Thank the Faculty of Social and Political Sciences, Raja Ali Haji Maritime University for giving an incentive to publish scientific papers for the 2020 budget year. Also, we thank the editorial team and reviewer of the journal governance and public policy of Muhammadiyah University of Yogyakarta who have worked by publishing this paper perfectly.

\section{REFERENCE}

Alika, R. (2020). Perkuat perlindungan sosial, Jokowi lanjutkan kartu prakerja di 2021. Katadata. https://katadata.co.id/ekarina/berita/5f36560c4612a/perkuat-perlindungan-sosialjokowi-lanjutkan-kartu-prakerja-di-2021

Ary, D., Jacobs, L. C., \& Razavieh, A. (1985). Introduction to research in education (3rd ed.). Holt, Rinehart, and Winston.

Bakhtiar, A., \& Qodir, Z. (2015). Implementasi program keluarga harapan sebagai upaya penanggulangan kemiskinan di kecamatan Berbah Sleman Tahun 2013. Journal of Governance and Public Policy, 2(2). https://doi.org/10.18196/jgpp.2015.0032

Consuello, Y. (2020). Analisis Efektifitas Kartu Pra-kerja di Tengah Pandemi Covid-19. ADALAH : Buletin Hukum \& Keadilan, 4(1), 93-100. https://doi.org/10.15408/adalah.v4i1.15479

Edward, G. (1980). Implementing public policy. Congressional Quarterly Press.

Grindle, M. S. (2017). Politics and policy implementation in the third world. Princeton University Press.

Habib, F., \& Laksono, Z. Y. T. (2019). Dual Track pengentasan kemiskinan: Kartu Menuju Sejahtera (KMS) dan Modal Sosial. Jurnal Penelitian Kesejahteraan Sosial, 18(2), 135-148.

Hogwood, B. W., \& Gunn, L. A. (1984). Policy analysis for the real world. Oxford University Press.

Iping, B. (2020). Perlindungan sosial melalui kebijakan program Bantuan Langsung Tunai (BLT) di Era Pandemi Covid - 19: Tinjauan perspektif ekonomi dan sosial. Jurnal Manajemen Pendidikan Dan Ilmu Sosial, 1(2), 516-526.

Kirk, Jerome., \& Miller, M. L. (1986). Reliability and validity in qualitative research. Sage Publications.

Kurniawansyah, H., Amrullah, M., Muslim, M., \& Nurhidayati, S. (2020). Konsep kebijakan strategis dalam menangani eksternalitas ekonomi dari COVID - 19 pada masyarakat rentan di indonesia. Indonesian Journal of Social Sciences and Humanities, 1(2), 130-139.

Lithur, N. (2015). Ghana national social protection policy.

Moleong, L. J. (2012). Metodelogi penelitian kualitatif. Remaja Rosdakarya.

Nurmalasyiah, \& Sumburwati. (2017). Implementasi kebijakan kartu perlindungan sosial di desa gumpa kecamatan Dusun Timur Kabupaten Barito Timur ( Studi program bantuan siswa miskin ). PubBis : Jurnal Pemikiran Dan Penelitian Administrasi Publik Dan Administrasi Bisnis, 1(1), 208-331. 
Ouma, M. (2019). Social protection policy making in Kenya.

Pressman, J., \& Wildavsky, A. (1973). Implementation. University of California Press.

Purwitasari, A. (2012). Implementasi Kebijakan Program Jampersal Di Kabupaten Lebak Provinsi Banten Tahun 2011. In Tesis Kesehatan Masyarakat.

Ramadani, T. (2019). Implementasi kebijakan pengelolaan komunikasi publik di kementerian energi dan sumber daya mineral. Jurnal Borneo Administrator, 15(1), 1-18. https://doi.org/10.24258/jba.v15i1.369

Ramadhan, A. (2020). Program kartu prakerja dianggap bermasalah, ini 7 rekomendasi dari Komisi Pemberantasan Korupsi (KPK) Republik Indonesia. KOMPAS.Com. https://nasional.kompas.com/read/2020/06/18/16302071/program-kartu-prakerjadianggap-bermasalah-ini-7-rekomendasi-kpk?page=all

Rohaeni, N. E., \& Saryono, O. (2018). Implementasi kebijakan program Indonesia pintar (PIP) melalui kartu Indonesia pintar (KIP) dalam upaya pemerataan penididikan. Indonesia Journal of Education \& Administration Review, 2(1), 193-204.

Rusyidi, B., Nuriyah, E., \& Meilani, L. (2017). Kebijakan perlindungan sosial dan pencegahan retrafficking bagi anak di Provinsi Jawa Barat. Prosiding Penelitian Dan Pengabdian Kepada Masyarakat, 140-154.

Samnuzulsari, T., \& Yudiatmaja, W. E. (2018). Clientelism and vote buying in local elections: A case study of Kartu Bintan Sejahtera. Masyarakat, Kebudayaan Dan Politik, 31(1), 72-83.

Satibi, I., \& Sudrajat, U. (2019). Strategi implementasi kebijakan penanggulangan kemiskinan di Kota Tasikmalaya. JISPO, 9(2).

Sentanu, I. G. E. P. S. (2015). Increasing trust in local government financial management and building integrity: efforts reform in Indonesia. Public Policy and Administration Research, 5(3), 206-213. www.iiste.org

Setiawan, R., \& Mahadiansar, M. (2020). Forecasting analysis : The Riau Islands local government role In Covid-19 disaster management. Jurnal Studi Pemerintahan, 11(3). https://doi.org/10.18196/jgp.113121

Shaban, N. (2011). Kenya national social protection policy.

Suharto, E. (2015). Peran perlindungan sosial dalam mengatasi kemiskinan di Indonesia : Studi kasus program keluarga harapan. Sosiohumaniora, 17(1), 22-28.

Sulhan, M., \& Sasongko, T. (2017). Implementasi kebijakan program penganggulangan kemiskinan melalui kartu penjaminan sosial dan kartu indonesia pintar pada masyarakat (Studi kasus di Kelurahan Kauman Kota Malang). JISIP : Jurnal Ilmu Sosial Dan Ilmu Politik, 6(1), 15-18. www.publikasi.unitri.ac.id

Sumarto, M. (2018). Perlindungan sosial dan klientelisme: Makna politik bantuan tunai dalam pemilihan umum. UGM Press.

Supriyanto, R., Ramdhani, E., \& Rahmadan, E. (2014). Perlindungan Sosial di Indonesia : Tantangan dan arah kedepan (I). Direktorat Perlindungan dan Kesejahteraan Masyarakat Kementeriaan PPN. www.bappenas.go.id

Surakhmad, W. (1980). Pengantar penelitian ilmiah: dasar, metode dan teknik. Tarsito.

Taylor, S. J., Bogdan, R., \& DeVault, M. L. (2015). Introduction to qualitative research methods : A guidebook and resource (Fourth). Wiley.

Vaziralli, S. (2020). A social protection response to COVID-19 in developing countries Policy brief. Policy Brief: Internasional Growth Centre, 4(1), 1-11. https://www.worldometers.info/coronavirus/

Warfa. (2019). Somalia social protection policy.

Xenia, S. (2014). Introduction: Social policy and social protection. In International Labour Organization (10th ed., Vol. 10). Universal Health Protection.

Yin, R. K. (2018). Case study research and applications: Design and methods (Sixth). Sage Publications.

Yudiatmaja, W. E. (2016). Implementasi dan evaluasi kebijakan publik. UMRAH Press.

Zed, M. (2014). Metode penelitian kepustakaan (3rd ed.). Yayasan Obor Indonesia. 
New facts about Jokowi's pra Kerjacard were accessed https://kumparan.com/kumparanbisnis/fakta-fakta-baru-soal-kartu-pra-kerja-jokowi$1 \mathrm{tCs} 2 \mathrm{Fz} 5 \mathrm{Fvx}$

Legilators ask for the pra Kerjacard program to be stopped (2020) to be accessed on https://www.medcom.id/ekonomi/bisnis/GbmYaV1b-legislator-minta-program-kartu-pra Kerja-dihhentian

Government : The Pra Kerja Card program for the procurement of goods and services (2020) is accessed at https://money.kompas.com/read/2020/06/20/064937626/pemerintahkartu-pra Kerja-bukan-lelang-pengadaan-barang-dan-jasa

Regulation of the Minister of Finance (PMK) Number 25 / PMK.05 / 2020 concerning the procedures for allocating, budgeting, disbursing, and accountability for pra Kerjacard funds.

Presidential Regulation Number 36 of 2020 concerning Work Competency Development through the Pra Kerja Card Program has been amended by Presidential Regulation Number 76 of 2020. 